\title{
The Class of 1838: A Social History of the First Victorian Novelists
}

\author{
Allen Riddell* $\quad$ Troy J. Bassett ${ }^{\dagger}$
}

2019-08-27

\begin{abstract}
To what extent does an individual's background, specifically their age, gender, and socio-economic background predict their becoming a novelist? Questions of this genre have been with us as long as the novel has been an object of study. Using new data, biographical details of every writer who published a novel in 1838 in the British Isles, we revisit the question of the relationship between social background and novel writing. Novelists in this cohort tend to emerge disproportionately from advantaged socioeconomic backgrounds- $83 \%$ of novelists come from non-working-class backgrounds. We also find that that men novelists are significantly more likely than women novelists to write under a name other than their legal name. The comprehensive data on the "Class of 1838 " made available here supports systematic study of the social history of novel writing, offering a replacement for existing opportunistic convenience samples of questionable reliability.
\end{abstract}

In 1961, Raymond Williams conducted the first study of the social origins of English authors in his landmark work of cultural history The Long Revolution (1961). For his data set, Williams collected biographical information of 350 authors born between 1470 and 1920 relying mainly on the original Dictionary of National Biography (DNB) as his source of information for biographical details, primarily the writers' social origins, educations, and non-literary occupations. The rationale for his investigation was the question of the connection between literature and novelists' social background:

\footnotetext{
*Indiana University Bloomington: riddella@indiana. edu.

†Purdue University Fort Wayne: bassettt@pfw. edu.
} 
We argue a good deal about the effects on literature of the social origins of writers, their form of education, their ways of getting a living, and the kinds of audience they expect and get. Theoretical questions, often very difficult, are of course involved in this argument, but the most obvious difficulty is the lack of any outline of facts by which some of the theoretical principles could be tested (Williams, 1961).

Williams' discussion of the social origins of writers, as determined by the "social and economic standing of the father," is the most thorough. As Williams's data show, over the course of five centuries, the social origins of writers do not reflect the social origins of individuals in the broader population. The majority of writers in Williams's analysis come from upper- or middle-class social origins. Their fathers tended to be either nobility, gentry, professionals, or (prosperous) merchants. Few of the writers' fathers were craftsmen, tradesmen, (poor) farmers, or laborers. (Williams uses these eight broad categories to describe a writer's social origins.) To narrow his focus to nineteenth-century writers, of the 56 writers in Williams' sample born approximately between 1780 and 1830, 43 (77\%) come from upper- or middle-class social origins. ${ }^{1}$ Assuming that the share of the population from upper- or middle-class social origins is smaller than $20 \%$, Williams' data show that individuals from the upper and middle classes are far more likely to become writers than individuals who grew up in working class families.

In spite of Williams's call for research in this area, the sociology of authorship in nineteenth-century English literary studies never took off as a subject of sustained research. Richard D. Altick followed Williams, publishing in 1962 a study of 1,100 British authors active between 1800 and 1935 based on the authors listed in the Cambridge Bibliography of English Literature, the DNB, and a few similar reference books (Altick, 1962) where he finds the social origins of his authors to be overwhelmingly upper and middle class. A few years later, Diana F. Laurenson studied the lives of 170 authors chosen randomly from 850 authors listed in the DNB and Everyman's Dictionary of Literary Biography who were born or died between 1860 and 1910 (Laurenson, 1969) and she likewise finds writers mainly arise from the middle class. The sociology of authorship endured a lapse of nearly two decades before Nigel Cross (1985) used applications to the Royal Literary Fund to access the lives of

${ }^{1}$ Williams writes that 57 individuals are in his sample for 1780-1830 but he only gives class origins for 56 . For other birth cohorts his numbers add up. These 56 writers which Williams places in the 1780-1830 cohort were born between 1770 and 1820 (Williams assigns writers to a cohort based on whether or not they were at least 10 years old during the designated period). When we later investigate the backgrounds of the writers who published a novel in 1838, nearly all of them would have been grouped in Williams' $1780-1830$ cohort. 
working author during the century-notably, his source, by its nature, includes many more writers who do not rate entries in the DNB or similar references. Gaye Tuchman used the DNB and the archives of the publisher Macmillan to assess the position of women authors in the literary marketplace during the nineteenth century (Tuchman, 1989) finding that women authors were systemically marginalized in the literary marketplace. John Sutherland in "The Victorian Novelists: Who were They?" examined the lives and literary careers of a sample of 878 Victorian novelists (Sutherland, 1995) in order to trace their career trajectories, focusing especially on the differences between men and women novelists. Since then, little activity in the sociology of authorship can be observed, despite developments that might seem to facilitate it, such as library digitization and expanding use of data-rich methods in literary studies (e.g., Bode (2012)).

Using the data in At the Circulating Library: A Database of Victorian Fiction, 1837-1901 (ATCL), this article studies the cohort of 81 fiction authors active in 1838. This cohort, which we call the Class of 1838, includes every writer who published a work of fiction in 1838 . (As the Victorian period begins in June 1837, we can safely label these authors published in 1838 as the earliest Victorian novelists.) Assuming that a novel published in 1838 (instead of a neighboring year) is conditionally independent of any particular demographic features associated with its author, then what we learn from the characteristics of novelists in this cohort likely holds generally for novelists active in the late 1830s and early 1840s. Our study differs in two ways from the earlier diachronic studies. First, by focusing on all the fiction authors published in a single year in Great Britain, our study provides information about a sample of writers who are likely to represent the population of novelists active during the late 1830s and early 1840s. Williams and the others draw their samples from pre-existing reference works, most notably the DNB. As several of these previous scholars have noted, these reference works suffer from selection biases of various kinds: in particular, the original DNB and later Oxford Dictionary of National Biography (ODNB) includes many more men authors than women authors and only authors who achieved a certain level of success or renown. ${ }^{2}$ Our study, by contrast, includes beginner and amateur authors, which the DNB tends to ignore. Second, our sample is more focused than previous studies, which base their conclusions on extremely thin samples spread across several decades or centuries. Even Williams has difficulty drawing conclusions from the comparison of sixteenth-century authors to twentieth-century authors given how greatly authorship and society have changed

${ }^{2}$ Altick's sample in particular suffers from this bias: of the 849 Victorian authors he examines, only 164 or $19 \%$ of them are women. The actual number of women authors was likely double this. Tuchman, in her study, attempted to correct for this bias in her samples taken from the DNB. 
in the last 500 years. Even the relatively shorter Victorian period includes three or four generations of authors as Altick's study surveys. By looking at all the active authors at a particular moment, our sample is more comprehensive and less subject to the selection biases of secondary sources.

Our study of the Class of 1838 encompasses three areas. First, following Williams, we examine the social origins of the authors (as judged by their fathers' occupations). Whereas the majority of adults living in the British Isle during this period were working class, the majority of the Class of 1838 originated in the middle and upper classes, a finding in line with that of Williams's study and later ones. Second, going beyond Williams, we trace the careers of the Class of 1838 by finding their ages at first published novel, their total novels written in their lifetimes, and the span of their careers. Though no significant differences were found between the careers of men and women authors, there was a general lack of persistence from these authors to write a second novel after publishing their first. And last, we inspected the title pages of the 87 published works of fiction in 1838 in order to investigate the ways in which authors presented themselves to readers. Contrary to expectations, men authors were significantly more likely than women authors to conceal their identities on their title pages.

\section{The Class of 1838}

Based on The English Catalogue of Books and other bibliographic sources, At the Circulating Library (ATCL) finds that 87 new fiction titles were published in 1838, of which 36 titles appeared in one-volume editions, 10 appeared in two-volume editions, and 41 appeared in three-volume editions, thus nearly three-fifths of fiction this year (59\%) appeared in expensive editions aimed at a circulating-library audience. Four publishers account for the majority of these titles (60\%): Henry Colburn published 18 titles, Richard Bentley 15 titles, Saunders and Otley 15 titles, and Longman 4 titles, with another 27 publishers publishing the remaining 35 titles. Of the titles published, men authors wrote 48 titles (55\%), women authors wrote 35 titles (40\%), and unknown authors wrote four titles. Eighty-one individual authors wrote these 87 fiction titles with a handful of authors accounting for two or more titles each: James Fenimore Cooper with two titles; Catherine Gore with three titles; Edward Bulwer Lytton with two titles; Eliza Paget with two titles; Lady Tuite with two titles; and William Ware with two titles. Two authors co-authored a title: the brothers John and Michael Banim wrote The 
Bit o' Writin' under the collective pseudonym "The O'Hara Family." 3

Using a range of biographical and genealogical sources, the lives of these authors were traced to find, in particular, information about the author's gender, birth, death, family, education, occupation, and writing career. Of the 81 individual authors, four authors cannot be traced and no identifying information (e.g., gender, nationality, or occupation) can be inferred from their attributions or published titles. For instance, the author of The Heiress and her Suitors (1 volume, Saunders and Otley) cannot be traced: the novel itself has no identifying information about the author on either its title page or in its brief preface addressed to the critics (which scrupulously avoids using gendered pronouns to describe him- or herself). Nor can the author's identity be traced through the publisher's records, which sadly do not survive for these years. The remaining 77 authors can be traced to some extent and some identifying information can be found about them: of them, the information about 13 authors can be classified as partial (e.g., only the author's gender is known) and the information about the remaining 64 can be classified as fairly complete. For instance, only partial information about Madame Brendlah, the author of Tales of a Jewess: Illustrating the Domestic Manners and Customs of the Jews (1 volume, Simpkin, Marshall), can be found: she describes herself in a preface as the daughter of a German-born physician and Dutch-Jewish mother who later converted to Christianity after residing in England. However, nothing further can be traced about her life including her birth date, birth place, or death date. (Arguably, the information in her preface may be fictitious as well, but in general we leaned towards accepting information self-reported by the authors.) Fortunately, a sizable majority of the authors can be completely traced since they achieved some level of fame-examples include Thomas Carlyle, Charles Dickens, Catherine Gore, Barbara Hofland, Edward Bulwer Lytton, and Frances Trollope. Hence, over $95 \%$ of the authors who published a fiction title in 1838 can be identified at least partially and nearly $80 \%$ can be identified completely (see Tables 1-3).

\section{Social Origins}

In terms of demographics, of the 77 authors who can be identified partially or completely, 46 men authors and 31 women authors published at least one work of fiction this year. Overwhelmingly, these authors were born in the British Isles with 36 authors from England, 8 authors from Ireland, and 11 authors from Scotland for a total of 55 authors $(71 \%$ of 77

\footnotetext{
${ }^{3} \mathrm{~A}$ machine-readable version of the data accompanies this article. Title information is also available on ATCL.
} 
authors). A further seven authors were born in then current or former British colonies: three authors from the United States, one author from Canada, and three authors from India. Of the three Americans-Cooper, Joseph Holt Ingraham, and William Ware-only Cooper spent any time in England (seven years from 1826-1833) but all three wrote their works mainly in the United States. The one Canadian, Thomas Chandler Haliburton, moved to England in 1837 where he remained until his death. The three authors born in India-Frederick Chamier, Harriet Anne Scott, and Robert Sulivan - all had colonial officials as fathers (the former two worked for the East India Company; the latter was a judge) and all had moved to England during their childhoods, so their birthplace in India should be considered accidental, not determinative of nationality (i.e., they are not "Indian" or Asian authors by any meaningful definition). Only one author, the German minister and author Christian Gottlob Barth, can be truly considered foreign since his work appeared in translation, the only such author in our sample and the only translated fiction title published in 1838. Thus, the vast majority of identified authors appearing in 1838 can be considered British subjects (77\% or 59 of the 77 authors) with relatively fewer authors (four) coming from outside the British Isles. Of the 18 authors whose birthplace cannot be traced, we make no assumptions, but presume a similar proportion if not more to be British subjects. This corresponds to Franco Moretti's observation in Atlas of the European Novel 1800-1900 that foreign works in translation all but disappeared from British circulating libraries in the early nineteenth century (Moretti, 1998). The year 1838, with one exception, features new fiction written by Anglophone authors, a decidedly insular literary marketplace.

Williams, in his study, focuses on the social origins of the authors in his sample. Based on the occupation of the authors' fathers, we used the same eight social classifications as Williams: nobility, gentry, professional men, merchants, tradesmen, farmers, craftsmen, and labourers. Of the 58 authors whose parentage could be traced, no author comes from nobility, 15 authors come from the landed gentry, 27 authors from the professional class, 6 authors from the merchant class, 5 authors from the tradesmen class, 2 from the farming class, 2 from the craftsmen class, and one from the laboring class (see Table 4). Williams coarsely groups these eight classes into into working (tradesmen, craftsmen, farmers, and labourers) and non-working class (nobility, gentry, professional, and merchants). Following Williams's partition, a majority of the identified authors belonged to the upper and middle classes, with 48 authors safely considered in the upper and middle classes (nobility, gentry, professional, merchant). Relatively fewer authors, only ten men, come from the lower class (tradesmen, farming, craftsmen, and labourers). 
The fifteen authors arising from the gentry all share a largely similar pathway into authorship. Born into relative comfort, if not wealth, both men and women author of the gentry enjoyed thorough educations and often foreign travel during their formative years. Most choose authorship as a pastime or a relatively easy income-producing career when or if necessary. In particular, five of the seven women novelists who come from the gentry initially chose to write for their own fulfillment rather than for economic gain. Hannah Dorothy Burdon (1800-1877) serves as the typical example: her father, an author in his own right, owned valuable estates in Durham and Northumberland, provided his daughter a generous education, and left her free to choose her own way in life which Burdon used to postpone marriage in order to paint landscapes and write novels. (In both occupations she obtained some just regard.) Two women novelists turned to fiction writing after financial reverses. After the death of her wealthy husband, the Countess of Blessington turned to silver-fork fiction to supplement her income (which was initially $£ 2000$ per year) but within a decade she depended almost entirely on her writing for her livelihood. Harriette Maria Smythies began writing fiction in her twenties which she continued after her marriage in 1842 mostly as a pastime. But her husband's bankruptcy a few years later led to them depending entirely on her writing and the Royal Literary Fund for support. The men novelists arising from the gentry differ in one significant way from the women novelists: all had some prior career before they embarked on authorship. For instance, Francis Glasse was commissioned as an army captain and as a retired officer on half-pay turned briefly to a career as poet and novelist. John Humphrey St. Aubyn and William Sinclair both took university degrees and entered Holy Orders - writing for both was a decided sideline as the former wrote two novels and the latter only one. Robert Smith Surtees, the second-son of a landed gentleman, trained as a solicitor before switching to the more agreeable work of sporting journalism, a profession he continued after he unexpectedly inherited his father's estate and no longer needed to write for money. Edward Bulwer Lytton deviates somewhat from this pattern: raised with every advantage, he attended Cambridge University and prepared for a life in politics. However, his marriage to Rosina Doyle in 1827 led his mother to cut his allowance so Lytton turned to fiction to supplement his income. Like Surtees, he continued to write fiction long after the financial necessity of writing disappeared.

Generally, the 33 authors from a safely middle-class background (professionals and merchants) account for most of the professional writers in the 1838 cohort - that is, those authors whose primary income comes from writing. The fifteen women novelists arising from these middle classes - those whose fathers were professionals or merchants - share many of 
the same attributes of the women novelists arising from the upper classes, having obtained their educations through schooling or self-directed reading. Marriage, if seems, was the intended career for all of them with authorship serving as supplements to or replacements of their husbands' income. Four women novelist this year were the daughters of clergymen or ministers (Elizabeth Holmes, Catherine Manners, Catherine Elizabeth Tonna, and Frances Trollope), two the daughters of physicians (Madame Brendlah and Catherine Godwin), and five the daughters of businessmen (Esther Copley, Catherine Gore, Barbara Hofland, Letitia Landon, and Julia Waddington). A good proportion of these middle-class women authors could be justly described as professional writers: for instance, Gore, Hofland, and Landon all had businessmen as fathers, all married, and all eventually lived by their pens. As one of the few careers open to women without formal qualifications, educated women could easily turn to fiction writing where even the negative stigma attached to fiction writing decreased over the course of the century.

Generally, the 18 men novelists arising from the middle classes also saw writing in a more career-minded way than the novelists arising from the upper-classes. For the most part, these novelists would need to work for a living, so they either entered directly or settled eventually into authorship, whether journalism or fiction. Four men novelists this year were the sons of clergymen or ministers (Matthew Barker, Robert Gleig, Richard Walker, and William Ware), four the sons of barristers or judges (Thomas Chandler Haliburton, Thomas Andrew James, Horace Smith, and Robert Sulivan), and three the sons of civil servants (Frederick Chamier, Dickens, and William Nugent Glascock). Not surprisingly, many men followed in the same career as their fathers: for example, both Walker and his father were clergymen; both Robert Macnish and his father were physicians; and both Robert Sulivan and his father were called to the bar. In all three cases, the sons added writing to the profession of their fathers. Compared to the middle-class women authors, fewer middle-class men authors (four) go on to live solely by their pens in authorship or journalism without another profession to fall back upon: Dickens whose father was a civil servant; Theodore Edward Hook whose father was a composer; G. P. R. James whose father was a physician; and Horace Smith whose father was a solicitor.

For the authors who published a work in fiction in 1838, only ten authors (all men) arise from the lower- or laboring-classes (tradesmen, farmers, craftsmen, and labourers). Five authors had fathers who worked a trade, including the sons of actors James Gregory Grant and Douglas Jerrold and the son of a woolen draper William Mullinger Higgins. Arguably, the Irish brothers John and Michael Banim may be better classed as "lower middle class" 
since the ODNB describes their father's profession as "the double occupation of farmer and trader in all the necessaries of a sportsman's and angler's outfit" whose business prospered enough to send his sons to school. The remaining three lower-class authors come from decidedly more humble origins. Thomas Carlyle's father was a mason who determined to send his son to school then university to study for the ministry which he ultimately rejected in favor of writing. Likewise, William Maxwell Hetherington's father was a gardener who encouraged his son to go to university to study for the ministry which he eventually joined. Only one author this year comes from the laboring class: Alexander Bethune's father was an agricultural day-labourer whose poverty limited his son's education to a bare minimum, though his school teachers recognized his talent. By fourteen years old, Bethune also worked as a labourer, but in later life he attended night schools and after encouragement began writing poems for local newspapers. His sole work of fiction, Tales and Sketches of the Scottish Peasantry, attained modest local success when published in 1838. All three of these lowest-class authors were coincidentally Scottish. These examples may suggest why women authors rarely arise from the lower classes: in the cases of the Banims, Carlyle, Hetherington, and Bethune, their early successes in grammar or Sunday schools singled the men out for possible further education, even university. Women in comparable social situations just did not have equal opportunities for similar schooling or encouragement.

\section{Fiction-Writing Careers}

For each author, we collected information about his or her fiction-writing career: the publication date of his or her first novel, the publication date of his or her last novel, and the total number of novels published in his or her lifetime. From this data, we could infer an author's age when he or she wrote his or her first novel using birth year when available, an author's career length in years, and an author's pace of novel production (see tables 1 and 2). Overall, career data for 77 identified authors could be found and show the median author wrote four novels in his or her lifetime in a career spanning 13 years (see Figure 1). For the 64 authors whose birth year was available, the median author wrote his or her first work of fiction at age 34.5 years old. 4

For the 46 men authors, the data show the median author wrote three novels in his lifetime in a career spanning 10 years. A large number of men authors in 1838 only wrote

\footnotetext{
${ }^{4}$ For the purposes of this study, we are focusing on the authors' fiction-writing careers and ignoring their nonfiction production.
} 
a single work of fiction: these eighteen authors (39\%) include the anonymous author of The Curate's Grave, the working-class author Alexander Bethune, essayist Thomas Carlyle, minster William Maxwell Hetherington, and clergyman Richard Walker. Clearly, fiction writing was not nor would be a primary career interest for these men as their fiction-writing careers begin and end with a single title. In the case of Carlyle, his sole novel Sartor Resartus began as a satirical article and grew into a serial novel quite by accident and he would never attempt fiction ever again (though he did go on to be a prolific writer of nonfiction). At the other end of the scale, twelve men authors wrote ten or more works of fiction: the most prolific novelists include G. P. R. James (67 novels), Cooper (32 novels), Lytton (25 novels), Dickens (21 novels), Thomas Miller (15 novels), and Horace Smith (15 novels). It is safe to say, the dozen men authors who each wrote ten or more titles made fiction writing one of their chief occupations - in the cases of James and Cooper their only occupations. As may be inferred, all of these more prolific authors had relatively long careers as novelists, for instance the 48 years between Lytton's first published novel in 1827 and his last novel in 1874 (published posthumously the year after his death). Several other authors rival Lytton's longevity: Smith's 44-year career, Michael Banim's 40-year career (7 titles alone and several more co-authored with his brother), James's 36-year career, Hook's 35-year career (14 titles), Miller's 35-year career, and Robert Sulivan's 35-year career (3 titles). (It should be said that the latter author was mainly a playwright who wrote the occasional novel.) Overall, the median pace of novel production for all of these men authors is 0.6 titles per year, but several authors exceed this pace. James wrote his 67 novels in 36 years which works out to nearly two titles per year (1.86 titles per year). Nearly all of these titles appeared in three-volume editions which makes this sustained productivity even more remarkable. In fact, James had several years in which two or three of his titles appeared, four years in which four titles appeared $(1839,1843,1844,1849)$, and one year in which five novels were published (1847). Two novelists averaged about one title per year: Cooper wrote his 32 novels in 31 years (1.03 titles per year) and Frederick Chamier wrote his 13 novels in 14 years ( 0.93 titles per year). It is no criticism to say that Chamier, Cooper, and James wrote fiction for money which well explains their pace of novel production. For comparison, both Lytton and Dickens wrote fiction closer to the median pace, 0.52 and 0.62 fiction titles per year respectively, which works out to about one novel published every other year. In the case of Dickens, his editing work and the serializations of his works (usually spread over a year or more) readily accounts for this pace of novel production; in the case of Lytton, his political career and serializations 
explains his pace of a published novel every other year. ${ }^{5}$

For the 31 women authors, the data show the median author wrote six novels in her lifetime in a career spanning 13 years. Compared to the men authors, the women authors show a higher productivity (double) to that of the men. About a third of women novelists in 1838 only wrote a single work of fiction: these nine authors (29\%) include Ann Adams, Catharine Booth, Madame Brendlah, Elizabeth Holmes, Camilla Needham, and Miss Randall. At the other end of the scale, ten women authors wrote ten or more works of fiction: the leading novelists include Catherine Gore (55 novels), Barbara Hofland (54 novels), Frances Trollope (34 novels), Hannah Jones (22 novels), Harriette Smythies (22 novels), Anna Maria Hall (15 novels), and Charlotte Elizabeth Tonna (15 novels). As with the prolific men authors, these ten prolific women authors made fiction writing their primary or only careers and enjoyed relatively long careers: for instance, the 41 years between Hall's first published novel in 1829 and her last novel in 1869. Several other women authors share Hall's longevity: Agnes Crosbie Hall's 39-year career (13 titles), Hofland's 38-year career, Smythies's 38-year career, Catherine Manners's 36-year career (6 titles), Gore's 35-year career, Hannah D. Burdon's 31-year career (14 titles), and Jones's 31-year career. Overall, the median pace of novel production for all of these women authors is about 0.8 titles per year (slightly higher than the men authors), but several authors exceed this pace by considerable margins. Catherine Godwin wrote her 7 novels in three years, a rate of over two titles per year (2.33 titles per year). Arguably, her works were one-volume fiction aimed at a juvenile audience, yet these three years show a sustained burst of production. Three women authors who averaged over one title per year combine productivity with longevity: Gore wrote her 55 novels in 35 years (1.52 titles per year); Hofland wrote her 54 novels in 38 years (1.42 titles per year); and Trollope wrote her 34 novels in 25 years (1.36 titles per year). These three authors can be safely characterized as professional authors whose writing accounted for their primary incomes. In the cases of Gore and Trollope, the bulk of their fiction appeared in multivolume fiction aimed at circulating-library readers, which compares closely to James's pace of production. Gore, like James, had several years in which she published three titles (1838, $1841,1843,1844,1845)$ and one in which she published four titles (1846). In the case of Hofland, her fiction combined some multi-volume fiction and many didactic works aimed at a juvenile reader. Unlike the men authors, the women authors of 1838 rarely had another

\footnotetext{
${ }^{5}$ In comparison, Sutherland used the 878 author entries in his magisterial The Stanford Companion to Victorian Fiction (1989; revised 2009) in a chapter "The Victorian Novelists: Who were They?" (1995) where he finds, among other facts, the average output of 15.7 fiction titles per man author with an average career length of 29.9 years. Needless to say, his sample includes a much higher proportion of professional authors such as Dickens, James, Lytton, and Miller than the Class of 1838.
} 
income-producing occupation, so the absence of such occupations must account for women authors' greater productivity and higher rates of production of fiction during this period. ${ }^{6}$

So, when did the novelists of 1838 begin their fiction-writing careers? The birth years of 64 authors of fiction in 1838 can be found: of them, the overall median age of first published novel is 34.5 years. Remarkably, the typical authors of this period embarked on writing fiction nearer to middle age than their youth. This median starting age holds equally for men and women authors. The median age of first published novel for men authors is 35 years $(n=40)$, ranging from Theodore Edward Hook who wrote his first novel The Man of Sorrow (1808) at age 20 years to John Poole who wrote his first novel Oddities of London Life (1838) at age 52 years. Few men authors began publishing fiction before 30 years of age (11 in total or 28\%): in addition to Hook, Horace Smith published his first novel at 21 years of age, Lytton published his first novel at 24 years of age, Dickens published his first novel at 25 years of age, and another seven authors published their first novels in their late twenties. In comparison, 17 men began publishing novels in their thirties, another 11 men began in their forties, and only one man began in his fifties. It seems men authors often delayed fiction writing due to preparing for, beginning, or working in alternate careers - that is, few men authors embarked straightaway as novelists. Matthew Henry Barker, better known as “The Old Sailor," serves as a typical example: he served in the Royal Navy, retired in 1825, and published his first fiction the following year at age 36 years. His post-retirement career trajectory was shared with fellow navy veterans Frederick Chamier, William Nugent Glascock, and Edward Howard; and army veterans Francis Glasse and George Robert Gleig. Poole only turned to fiction writing in his fifties after a long and successful career as a dramatist - in his case and in the cases of other men authors such as the several clergymen novelists, fiction writing can only be characterized as a sideline to an already existing career or a post-retirement occupation.

The median age of first published novel for women authors is 33 years $(n=24)$, ranging from Lady Scott who published her first novel The M. P.'s Wife (1838) at age 19 years to Lady Tuite who published her first novel Edwin and Mary (1838) at age 74 years. Generally, women authors began publishing fiction somewhat earlier than men authors. Nearly half of the women authors began publishing fiction before 30 years of age (10 in total or 42\%): in addition to Lady Scott, Catherine Booth published her first novel at age 22 years, four authors published their first novels at 25 years (Gore, Agnes Crosbie Hall, Jones, and Smythies), and another three authors published their first novels in their late twenties. Another 10

${ }^{6}$ Of his 878 authors, Sutherland, op. cit., finds women authors averaged 21 fiction titles with an average career length of 35.2 years. Again, his sample includes a high proportion of professional authors such as Gore and Trollope than the Class of 1838. 
women began publishing novels in their thirties, only one woman began in her forties, and another two women began in their fifties, with Lady Tuite beginning her in seventies (after a successful poetry-writing career). Compared to the men, the vast majority of women authors began writing fiction well before their fortieth birthdays (20 authors in total or $83 \%$ ). Women authors often faced fewer obstacles or external time commitments to entering the fiction-writing marketplace, so could turn their hands to novels while relatively young. Whereas many men turned to fiction writing after age forty as a secondary or post-retirement occupation, women authors who turned to fiction after age forty primarily did it for money. For instance, the Countess of Blessington published her first novel in 1838 at 44 years old due to the death of her husband and the loss of his income and she would write eleven more over the next 17 years. Frances Trollope, following her successful travel book Domestic Manners of the Americans (1832), published her first novel the same year at age 53 years old after the repeated financial failures of her husband and she would write another 33 novels in the next 24 years. For middle- and upper-class women in the comparable financial straits of Blessington and Trollope, fiction writing offered one of the few careers freely open to women without professional training or the necessity of leaving home.

As John Sutherland observes, "one of the main predisposing factors to writing Victorian novels was to have a close relative, or intimate acquaintance, who wrote Victorian novels"(Sutherland, 1995). For the identified authors of fiction in 1838, nearly a third (25 of 77 authors or $33 \%$ ) had another close family member who was also an author (see Table 5). This prevalence of family relationships between authors in 1838 is in keeping with an earlier study that found one in six of Victorian novelists had another family member who also wrote a novel(Bassett, 2015). The most remarkable novelist in this regard is Frances Trollope: her brother Henry Milton wrote two novels; her husband Thomas Anthony Trollope wrote two nonfiction works; her three children (Thomas Adolphus Trollope, Anthony Trollope, and Cecilia Tilley) all wrote novels; her daughter-in-law Frances Eleanor Trollope (née Ternan; wife of Thomas) wrote novels; and her grandchild Henry Merivale Trollope (son of Anthony) wrote a novel. The family of William Sinclair nearly matches Trollope's family in literature: his father Sir John Sinclair wrote historical and statistical works, his sister Catherine Sinclair wrote novels, and his two brothers George and John each wrote historical and religious works. Ann Fraser Tytler also came from a literary family: she was the daughter of the historian Alexander Fraser Tytler and the sister of historians Patrick Fraser Tytler and William Fraser Tytler. The most common relationship between authors is siblings where nine of the 77 identified authors had a brother or sister who also wrote a book (fiction or nonfiction) (12\% 
of authors). In addition to Sinclair, Trollope, and Tytler and their siblings, John and Michael Banim co-authored a collection of fiction in 1838 and the brothers would go on to co-author and independently author several more works of fiction. An equally common relationship between authors is parents to authors: nine of the 77 identified authors had a child who also wrote a book (12\% of authors). As with Frances Trollope, an author parent could pave the way for her children's entry into literary life through contacts or just the common name: other examples include Cooper's daughter Susan Fenimore Cooper, Douglas Jerrold's son William Blanchard Jerrold (who in turn had a daughter novelist), and Lytton's son Edward Robert Bulwer-Lytton. Another common relationship between authors was husband and wife where seven of the 77 identified authors had a spouse who also wrote a book (9\% of authors). Notable example of married authors include Anna Marie and Samuel Carter Hall, Edward and Rosina Bulwer Lytton, and Lady Scott and Sir James Sibbald David Scott. Last, relatively few authors in 1838 had a parent who wrote a book-only five of the 77 identified authors (7\%). In addition to Sinclair and Tytler mentioned above, Catherine Booth's father David Booth wrote The Art of Brewing (1829) and Hannah Burdon's father William Burdon wrote several philosophical works. Whereas all authors had a strong likelihood of being related to another book author, women authors generally were more likely to have family-member authors $(39 \%)$ than men authors $(28 \%)$ which suggests another significant career difference between men and women novelists.

Finally, how persistent were new novelists in continuing to write fiction? In 1838, 38 novelists published their first works of fiction, but only 11 go on to ever publish another work of fiction (29\%) (see Table 6 and Figure 1). Remarkably, for this cohort of authors, a large majority of new novelists abandon fiction writing altogether after their first published attempt. In the case of Carlyle, temperament not bad reviews prompted him to begin and end his novel-writing career with Sartor Resartus, a novel only published in book format because of readers' demands for it. For many men novelists in particular, the writing of a novel can only be classified as a pastime or an aside to their primary careers. For instance, several clergymen or ministers (e.g., William Maxwell Hetherington, Francis John Rankin, and William Sinclair) and several barristers (e.g., Thomas Andrew James and Michael Joseph Quin) found enough time to pen a novel amid other duties. On the other hand, the lone working-class author, Alexander Bethune, struggled to find time to write his poetry and fiction, thereby limiting his published output. Death in a few cases ended careers just as they begun: philosopher and physician Robert Macnish died suddenly in 1837 and his lone fictional work was published posthumously (though he did write several other nonfiction 
works in his short life); and Edward Lanzer Joseph died in 1838 in the West Indies the same year as his lone novel Warner Arunell and his history of Trinidad. For some women novelists in particular, marriage and children effectively ended fiction-writing careers: for instance, Catharine Booth at age seventeen wrote an anonymous novel Walter Deverell then married a manufacturer and gave up writing thereafter; and Louisa Lane likewise wrote a novel at a young age then married a clergyman and paused her writing career until his death in 1864 when thereafter she wrote several scientific works. Other authors' reasons for ending their careers are lost in the fog of history. The title page of Tales of a Jewess by Madame Brendlah labels them a "first series" but no second series ever appeared-clearly, Brendlah and her publisher intended more of her fiction-writing career which due to some undiscovered reason began and ended in 1838.

This low level of new novelist persistence holds equally for both men and women novelists. Of the 24 men novelists whose first published fiction appeared in 1838, only 7 novelists go on to publish another fiction title (29\%): Christian Barth, Augustus Collingridge, William O’Neil Daunt, Douglas Jerrold, John Poole, Robert Smith Surtees, and William Ware. Several of these persistent men novelists-Daunt, Jerrold, Poole, and Surtees-made writing their primary career, whether in fiction, journalism, or playwriting. Of the 14 women novelists whose first published fiction appeared in 1838, only 4 novelists go on to publish another fiction title (29\%): Lady Scott, Harriette Smythies, Lady Tuite, and Julia Waddington. Lady Tuite, it should be noted, barely counts as a persistent novelist: born in 1764, she wrote several collections of poetry before publishing two short novels aimed at juvenile readers in 1838 at the age of 74 years old. Though she lived another twelve years, she did not continue her fiction writing. Both Lady Scott ( 8 fiction titles) and Smythies (22 fiction titles) carried on to make fiction writing a significant career. So, what factors explains the high failure rate-verging on three out of four authors-of new novelists in 1838? Obviously, as these examples illustrate, personal circumstances or even death often played a significant role in whether or not a novelist persisted in writing fiction. Given the economic turmoil of the 1840s, some publishers may have curtailed the publishing of fiction by relatively new authors, though the overall rate of new title production generally increased over the 1840s. Or, the year 1838 may be an outlier - a particularly bad year for new novelists, whether for economic, personal, or social reasons (two novelists-Joseph and Macnish-did die after their first and last novels). A cursory look at the year 1862 shows only 43 of 96 new novelists that year persisted and wrote at least one more novel (45\% of authors), which shows fewer than half of new novelists persisted. Clearly, future investigation is warranted since currently 
ATCL has nearly 3,800 authors, of which about $44 \%$ only wrote one work of fiction, which shows the general lack of persistence among novelists may be fairly common.

\section{Title-Page Attributions}

So, how did these novelists present themselves on their title pages to the public? While publishers ultimately had the authority to print whatever attribution they wished on title pages with their imprint, in the nineteenth century, publishers most often (but not always) allowed authors to determine their own attributions. So, in this analysis, we assume that the authors of novels in 1838 had the freedom to craft their own attributions. Using physical or digital copies, we successfully examined 85 of the 87 titles published in 1838. (In fact, 77 of the 87 titles had digital surrogates through the British Library, Google Books, or Hathitrust: a rather remarkable statistic itself.) The two titles not examined-Burton: or, The Sieges by Joseph Holt Ingraham and The Premature Marriage by an Observer-could not be located in any library and thus were omitted from the following analysis. Wiley and Putnam, the publisher of the former title, issued advertisements for Ingraham's novel, but perhaps they never ultimately printed copies. Darton and Clark, the publisher of the latter title, issued advertisements and sent review copies to at least two magazines who reviewed the novel, so they must have printed at least some copies of the book. Of the surviving 85 titles, we classified the title pages into one of four categories (see Table 7). First, 40 title pages used the author's legal name in some form, such as Mrs. Barwell, Hannah D. Burdon, Captain Chamier, or Thomas Miller. In some cases, the legal name included other identifying information such as marital status (for women), occupation (for men), or lists of other titles authored. Second, 17 title pages only used "By the Author of" or (more rarely) "By the Authoress of" as an authorial identity: for instance, George Robert Gleig, the author of Chelsea Hospital, described himself as "By the Author of 'The Country Curate,' 'The Subaltern,' 'The Chronicles of Waltham,' etc." and Catherine Gore, the author of Mary Raymond, described herself as "By the Authoress of 'Mothers and Daughters' etc. etc." Third, 13 title pages used a pseudonym to conceal the authors' identities, some of which would have been obvious to contemporary readers such as "By a Lady of Rank" or "By an Officer" and some of which would have been harder to question such as "Lieut. Hatchway, R. N." and "Denis Ignatius Moriarty" [i.e., William O'Neill Daunt]. Fourth, 15 title pages contain no authorial information whatsoever, hence they are truly anonymous: for instance, the title pages of both The Heiress and her Suitors and Mrs. Wilberforce are blank between 
the title and the publisher's imprint. Already, nearly half of the title pages (47\%) used the author's legal name as the attribution; over $80 \%$ of the title pages had some attribution (legal name, "By the Author of", or pseudonym); and less than one fifth of the title pages (18\%) were truly anonymous.

Using the known genders of the 81 authors (hereafter called "person gender"), we can trace the attribution practices of men and women authors and determine any correlation between their person gender and their "attribution gender" (that is, whether their title page attribution or other paratextual matter conveys any gender information). For men authors, the 47 title-page attributions divided fairly evenly between legal names (17 attributions), "By the Author of" (10 attributions), pseudonyms (10 attributions), and anonymous (10 attributions). Surprisingly, little more than a third of men authors used their legal names on their title pages $(36 \%)$. Those that did so often included information about their occupations: the eight authors who did so (with their attributions) are Rev. C. G. Barth; Alexander Bethune, Labourer; Captain Chamier, R. N.; A. Collingridge, Esq.; J. Fenimore Cooper, Esq. (two title pages); Captain Glascock, R. N.; Rev. W. Sinclair, M. A., Minister of St. George's, Leeds; and Robert Sulivan, Esq. (In these cases, "esquire" connotes some legal training or occupation, not just an honorific.) Notably, E. L. Joseph added "of Trinidad" to his attribution-likely a bid to add credibility to his novel Warner Arundell: The Adventures of a Creole. Of those men who used pseudonyms, the majority (6 of 10 authors) used a gender-conforming alias, where the person gender matches the attribution gender: they are, "An Officer," “The Old Sailor," "Denis Ignatius Moriarty," “Lieut. Hatchway, R. N.," “A Country Minister," and "Paul Pry"-tellingly, one of these pseudonyms imitate the inclusion of occupation information seen in the legal name attributions. Three of the ten pseudonyms are gender ambiguous_- "Boz" (used by Dickens), "The O'Hara Family" (used by the brothers John and Michael Banim), and "A Sub-Utopian" (used by Richard Walker) — and only one is arguably gender non-conforming: "Della" (used by Archibald Nagle). So, of the title pages with some form of attribution, men authors generally conformed to their person genders in their attribution genders. Over a fifth of men-authored titles appeared anonymously (10 of 47 titles), a rather large fraction, which means, more often than not, men authors in 1838 concealed their legal identity behind "By the author of," pseudonyms, and anonymous attributions $(64 \%)$.

In the case of women authors, the 35 title-page attributions strongly favor legal names (22 attributions) over "By the Author of" (7 attributions), pseudonyms (3 attributions), and anonymous (3 attributions). Thus, in this year of novel publishing, authorial attribution 
practice differed sharply among men and women authors where women authors were almost twice as likely to use their legal names as attributions than men authors (63\% to $36 \%$ ). Of the twenty-one women authors who used their legal names, the majority (11 authors) denoted their marital status: for instance, the Countess of Blessington, Mrs. Hofland, Miss Landon, or Lady Stepney. One women author listed both her married and maiden names: the title page for Tales and Sketches, Historical and Domestic includes the attribution "By Mrs. D. Clarke, (late E. A. Ingram)," a reminder of the unique difficulty of name changes faced by women authors using their legal names in the literary marketplace. Of the five women authors who used "By the Author of" as their attribution, two authors adapted it to "By the Authoress of": Catherine Gore (3 titles) and Harriet Maria Smythies (1 title). Three women authors used pseudonyms and all conform to the person gender of the author-in fact, the pseudonyms emphasize their person gender: "A Lady of Rank" (used by an unknown woman), "A Protestant Lady" (used by Ann Adams), and "A Country Parson's Daughter" (used by Elizabeth Holmes). Only three titles by women authors appeared anonymously: Walter Deverall by Catherine Booth, The M. P.'s Wife by Lady Scott, and Misrepresentation by Julie Waddington. Like the men authors, women authors in this publishing year generally conformed to their person genders in their attribution genders: 29 of the 35 title pages (83\%) denote an attribution gender matching the person gender. Thus, far from hiding their legal identities or person gender, women authors in 1838 very frequently revealed both their legal identities and person gender, a finding rather at odds with the common belief that women writers in the nineteenth century often hid behind (male) pseudonyms and anonymity. ${ }^{7}$

\section{Conclusion}

Whether or not an individual pursues a career as a novelist is clearly influenced by their social background. We find, supporting Williams's early research, that the ranks of professional writers active in 1838 are disproportionately occupied by those with financial means. This is hardly surprising as writing, like reading, requires time and a variety of physical and environmental supports that were then, as now, not universally available.

\footnotetext{
${ }^{7}$ An examination of twenty randomly selected titles from 1862, half by men authors and half by women authors, shows general persistence in these attribution practices. In the 1862 sample, 10 title pages used the authors' legal names, 3 used "by the author of," 4 used pseudonyms, and 3 were anonymous which roughly matches the distribution found in 1838. By person gender, the attribution practices diverge. Whereas women authors equally used their legal names (4 title pages), "by the author of" (3 title pages), or anonymous ( 3 title pages), men authors decidedly shifted to using their legal names (6 title pages) or pseudonyms (4 titles pages). Clearly, more investigation of title-page attribution practices is warranted.
} 
The social origins of the novelists in the Class of 1838 conform closely to Williams' observations of writers in his 1780-1830 cohort where he found that 43 out of 56 writers (77\%) had social origins in the upper- and middle-classes. In the Class of 1838 we find a similar share: of the 58 writers for whom we were able to determine the father's occupation, 48 writers $(83 \%)$ had social origins in the upper- and middle-classes. As both samples are relatively small, claiming that there is a significant difference between the percentages merits a formal statistical test, such as Fisher's exact test. Using this test, we find no statistically significant difference. ${ }^{8}$ Needless to say, our data support the conclusion that the social origins of novelists do not reflect the distribution of social classes in the broader population. Novelists are considerably more likely to emerge from upper- and middle-class social origins than the lower classes.

Going beyond Williams, we can estimate the strength of the association between social origin and the novelistic profession in 1838. (Williams does not offer any estimate of what share of the broader population had social origins associated with his eight groupings.) Data from a sample of the 1850 census, studied in Long (2005), suggests that between $2 \%$ and $18 \%$ of the population had a father whose social and economic standing would be described as upper- or middle-class according to Williams' schema. ${ }^{9}$ If we assume that these figures hold for adults in 1838 and we accept that the Class of 1838 data adequately describes the social origins of all novelists (not just those who published in 1838), then a novelist in 1838 is between 5 and 42 times more likely to come from upper- or middle-class social origins than an individual drawn at random from the broader population.

After investigating the social history of the authors of fiction in 1838, it may be worth going back and considering the sample sets Williams and others used in their social histories of authorship, in particular the use of the original Dictionary of National Biography (DNB) or its later incarnation the Oxford Dictionary of National Biography (ODNB) as sources. Without question, the individual entries in the ODNB represent the best knowledge of their subjects written by experts in their respective fields. However, since its inception, the selection

\footnotetext{
${ }^{8}$ Fisher's exact test works on a two-by-two contingency table. To construct such a table we partition the eight occupational categories into two categories, working class and not working class. Working class includes craftsmen, tradesmen, (poor) farmers, and laborers. Not working class includes nobility, gentry, professionals, and merchants. Williams' $1780-1830$ group has 13 working class, 43 not working class. Class of 1838 has 10 working class, 48 not working class.

${ }^{9} \mathrm{We}$ are counting Class 1 (Professional) and Class 2 (Intermediate) as potential matches for the four most economically-advantaged categories in Williams' schema. Counting both Class 1 and Class 2 together gives the $18 \%$ figure. Assignment to the different classes depends largely on the number of employees an individual reported on the census. Individuals in Class 1, for example, would typically have one employee per household member.
} 
process for inclusion has been opaque and subject to various biases, especially in terms of subject gender. Each identified author of fiction in 1838 (less the four foreign authors and the nine nameless or anonymous authors) was checked for an entry in the original DNB and its early supplements (1885-1906) and in the ODNB (2019) (see Table 8). Unsurprisingly, all authors who appeared in the DNB also appear in the ODNB, but not vice versa, as the latter work continues to add entries from all periods. Overall, $60 \%$ of the authors of fiction in 1838 currently have an entry in the ODNB (41 of 68 authors), up from the $53 \%$ of the authors with an entry in the original DNB (36 of 68 authors) - a rather remarkable overall result which includes authors from all socio-economic classes. However, as expected, the results by gender show that men authors are included at a higher rate than women authors. In 1838, men account for 39 of the 68 authors examined (57\%), but account for $67 \%$ of the entries in the DNB and $63 \%$ of the entries in the ODNB. In comparison, women account for 29 of the 68 authors examined (43\%), but account for $33 \%$ of the entries in the DNB and $37 \%$ of the entries in the ODNB. (These numbers make Altick's sample of Victorian authors from the DNB, of which $19 \%$ were women, appear even more strange.) Though the new ODNB has made improvements, judging by this particular year, the proportion of men authors continues to exceed both the prevalence in the general population of novelists and the proportion of women novelists. Seemingly, the selection process for the original DNB favored second- (and even third-) tier men novelists for inclusion over comparable women novelists. In the editors' defense, many of these men novelists had other non-literary careers that contributed to their inclusion-for instance, the host of retired naval officers and sailors such as Barker, Chamier, Glascock, and Howard. Women authors, in general, often lacked such varied occupations. On the other hand, several women novelists from 1838 appear unfairly overlooked: for instance, neither Burdon nor Tytler have entries yet both their author fathers do (only the latter author is mentioned in passing in her father's entry). It remains an important task to quantify the bias, if any, in the ODNB for later years in the century.

A detailed, year-by-year accounting of the social origins of novelists contributes to our understanding of the factors that influence an individual's becoming a writer. This, in turn, contextualizes the creation of individual works, something traditionally of interest to researchers in literary studies. As we discussed, although great writers may be born anywhere, those that become professional writers come disproportionately from certain social backgrounds. Future research should continue the work here and seek a fuller account of when and how the association decreased (if it did decrease uniformly). An account of the changing association between social origins and literary careers is a critical part of any 
narrative of 19th century literary production. And although a comparative social history of the profession in the 19th century would likely be more useful than one focused, as ours does, on a limited geographic and linguistic context, the text industry in the British Isles is an important and influential one. The patterns of production and the relations among writers, publisher-booksellers, and financial markets that characterize the global publishing industry (or, at least, the text industries centered in New York and London) resemble in many ways the relations which emerged in London in the 1830s and 1840s (Raven, 2007, pp. 328-329). 


\section{References}

\section{References}

Altick, Richard D. (1962). "The Sociology of Authorship: The Social Origins, Education, and Occupations of 1,100 British Writers, 1800-1935". In: Bulletin of the New York Public Library 66, pp. 389-404.

Bassett, Troy J. (2015). "Sister Acts: The Prevalence of Literary Families in the Victorian Period". In: Studies in Victorian and Modern Literature: A Tribute to John Sutherland. Fairleigh Dickenson UP, pp. 103-15.

Bode, Katherine (July 2012). Reading by Numbers: Recalibrating the Literary Field. English. New York: Anthem Press. ISBN: 978-0-85728-454-9.

Cross, Nigel (1985). The Common Writer. English. Cambridge: Cambridge University Press.

Laurenson, D. F. (1969). “A Sociological Study of Authorship”. In: The British Journal of Sociology 20.3, pp. 311-325. ISSN: 0007-1315. DOI: 10.2307/588955.

Long, Jason (2005). "Rural-Urban Migration and Socioeconomic Mobility in Victorian Britain". In: The Journal of Economic History 65.1, pp. 1-35. ISSN: 0022-0507.

Moretti, Franco (1998). Atlas of the European Novel, 1800-1900. English. London: Verso.

Raven, James (2007). The Business of Books: Booksellers and the English Book Trade, 14501850. New Haven [Conn.] ; London: Yale University Press. IsBn: 978-0-300-12261-9.

Sutherland, John (1995). “The Victorian Novelists: Who Were They?” In: Victorian Fiction. Springer, pp. 151-164.

Tuchman, Gaye. (1989). Edging Women Out: Victorian Novelists, Publishers, and Social Change. New Haven: Yale University Press. IsBn: 0300043163 (alk. paper).

Williams, Raymond (1961). The Long Revolution. English. London: Chatto \& Windus. 


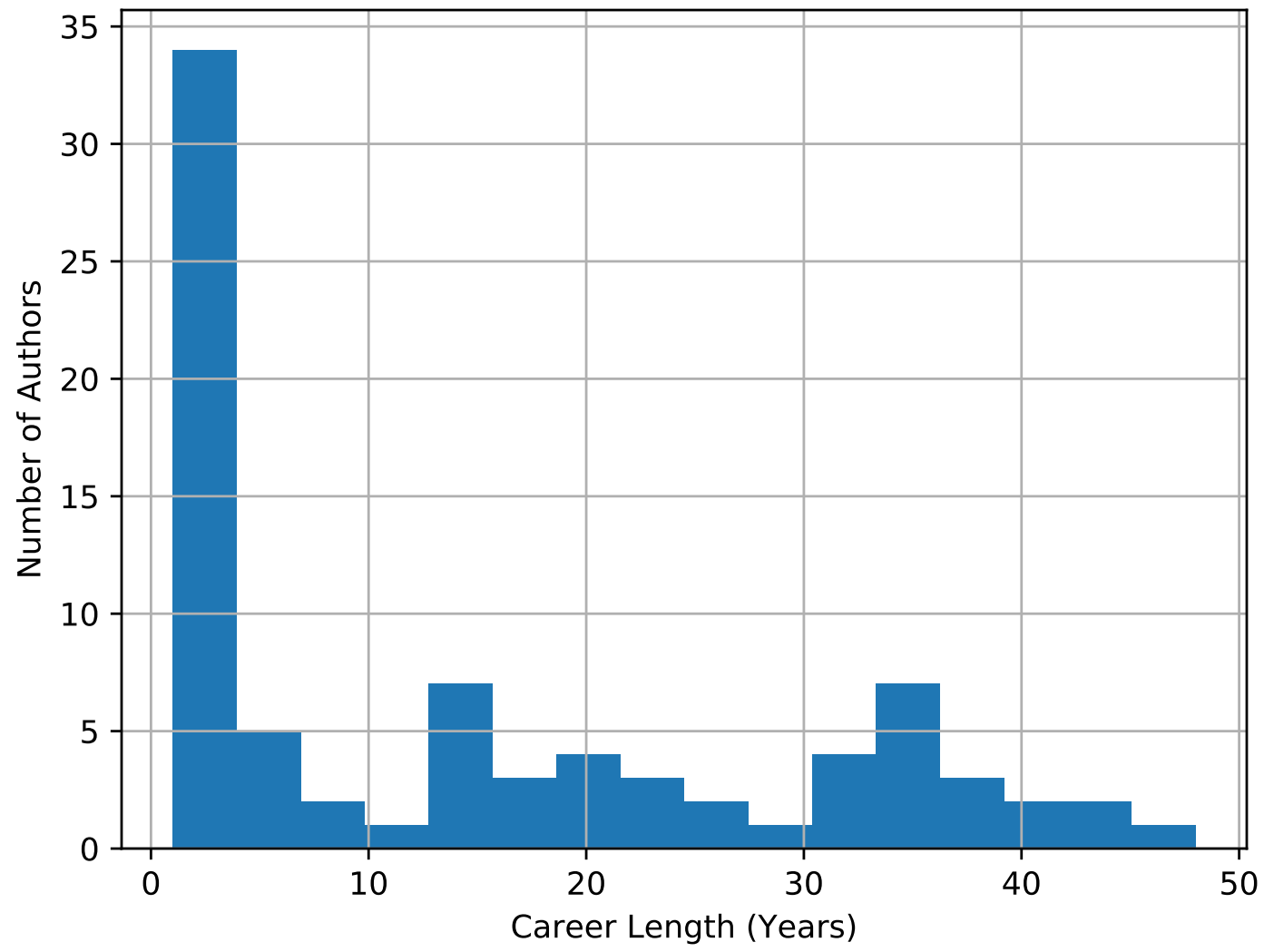

Figure 1: Author career lengths measured in years $(\mathrm{N}=81)$. Authors who published only one work of fiction are counted as having a career length of 1 year. 


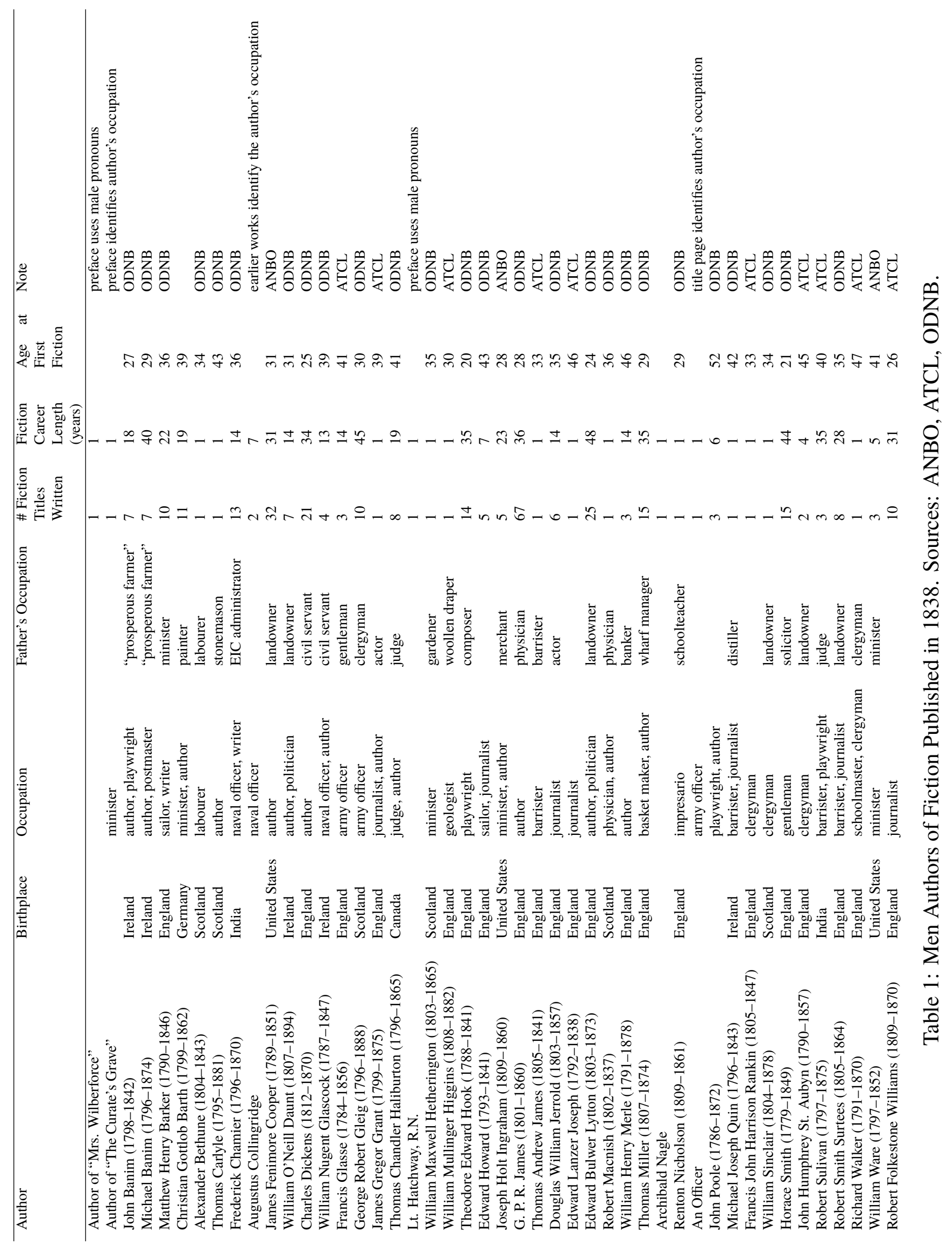




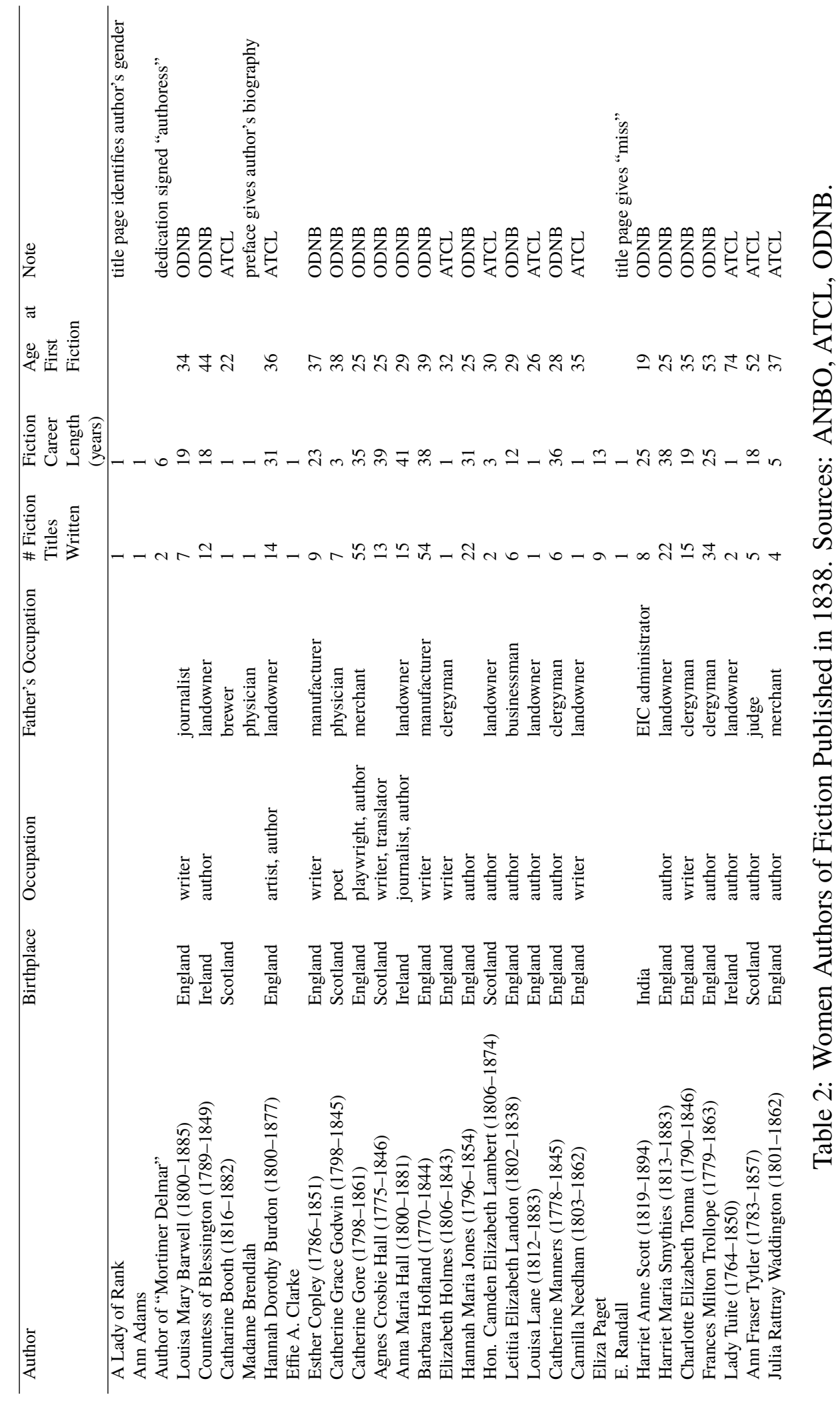




\begin{tabular}{ll}
\hline Author & Note \\
\hline Author of "The Heiress and her Suitors" & Preface avoids using gendered pronouns \\
Author of "Historical Tales of Historical Counties" & Preface avoids using gendered pronouns \\
Author of "Piers de Gaveston" by E. E. C. & Preface avoids using gendered pronouns \\
Author of "The Premature Marriage" by an Observer &
\end{tabular}

Table 3: Unknown Authors of Fiction Published in 1838.

\begin{tabular}{lll|l}
\hline Father's Occupation & Men Authors & Women Authors & Total \\
\hline Nobility & 0 & 0 & 0 \\
Gentry & 7 & 8 & 15 \\
Professional & 17 & 10 & 27 \\
Merchants & 1 & 5 & 6 \\
Tradesmen & 5 & 0 & 5 \\
Farmers & 2 & 0 & 2 \\
Craftsmen & 2 & 0 & 2 \\
Labourers & 1 & 0 & 1 \\
\hline Total & 35 & 23 & 58
\end{tabular}

Table 4: Social Origins of Authors of Fiction Publishing in 1838. Based on the categories used by Raymond Williams.

\begin{tabular}{l|ll}
\hline Author Gender & $\begin{array}{l}\text { Has a Family Member who } \\
\text { Authored a Book }\end{array}$ & $\begin{array}{l}\text { Does Not Have a Family } \\
\text { Member who Authored a } \\
\text { Book }\end{array}$ \\
\hline Men Authors & 13 & 33 \\
Women Authors & 12 & 19 \\
\hline Total & 25 & 52 \\
\hline
\end{tabular}

Table 5: Authors of Fiction in 1838 with Family-Member Authors. Note: Family member defined as parent, sibling, spouse, or child.

\begin{tabular}{l|ll}
\hline Author Gender & $\begin{array}{l}\text { Author of Only One Fiction } \\
\text { Title }\end{array}$ & $\begin{array}{l}\text { Author of Two or More Fic- } \\
\text { tion Titles }\end{array}$ \\
\hline Men Authors & 17 & 7 \\
Women Authors & 10 & 4 \\
\hline Total & 27 & 11 \\
\hline
\end{tabular}

Table 6: Persistence of New Authors of Fiction in 1838. New authors are authors who published their first novel in 1838 . 


\begin{tabular}{llllll}
\hline Author's Gender & $\begin{array}{l}\text { Legal Name on "By the Au- } \\
\text { Title Page }\end{array}$ & $\begin{array}{l}\text { Pseudonymous } \\
\text { thor/ess of" } \\
\text { Title Page }\end{array}$ & $\begin{array}{l}\text { Anonymous At- } \\
\text { ontribution } \\
\text { Title Page }\end{array}$ & $\begin{array}{l}\text { on } \\
\text { Page }\end{array}$ \\
\hline Men Authors & 17 & 10 & 10 & 10 \\
Women Authors & 22 & 7 & 3 & 3 \\
Unknown Authors & 1 & 0 & 0 & 2 \\
\hline
\end{tabular}

Table 7: Title-page Attributions of Fiction Published in 1838. Note: Two title pages not seen.

\begin{tabular}{llllll}
\hline & $\begin{array}{l}\text { Identified authors } \\
\text { of fiction in 1838 }\end{array}$ & $\begin{array}{l}\text { Entry in DNB } \\
(1885-1906)\end{array}$ & Entry in ODNB & $\begin{array}{l}\text { No Entry in } \\
\text { ODNB }\end{array}$ & \\
\hline Men authors & 39 & 24 & 26 & 13 & \\
Women authors & 29 & 12 & 15 & 14
\end{tabular}

Table 8: Authors of Fiction in 1838 with DNB or ODNB Entries. Note: All authors who appeared in the DNB also appear in the ODNB, but not vice versa. Foreign authors (e.g., J. F. Cooper) and authors without names (e.g., the author of Mrs. Wilberforce) excluded. 